\title{
$\begin{array}{lllllllllllllll}M & \text { A } & \text { T } & \text { E } & \text { R } & \text { I } & \text { A } & € & Y\end{array}$
}

\section{Konrad Bobiatyński}

https://orcid.org/0000-0002-9832-3048

Instytut Historyczny Uniwersytetu Warszawskiego

\section{Testament strażnika wielkiego litewskiego Samuela Kmicica}

\begin{abstract}
Zarys treści
Testament Samuela Kmicica jest bardzo cennym źródłem do badania mechanizmów awansu społeczno-majątkowego oficerów średniego szczebla armii litewskiej w drugiej połowie XVII wieku. Jego autor był jednym z ważniejszych współpracowników trzech hetmanów - Pawła Jana Sapiehy, Michała Kazimierza Radziwiłła i Kazimierza Jana Sapiehy. Dokument ten zawiera wiele istotnych informacji na temat powiązań klientalnych i finansowych testatora, znacznie też poszerza stan wiedzy o jego działalności fundacyjnej czy też stosunkach rodzinnych.
\end{abstract}

\begin{abstract}
Samuel Kmicic's last will and testament is a very valuable source for the study of the mechanisms of social and financial advancement of middle-level officers of the Lithuanian army in the second half of the seventeenth century. Its author was one of the most important associates of three hetmans: Paweł Jan Sapieha, Michał Kazimierz Radziwiłł, and Kazimierz Jan Sapieha. The document contains a number of important information about the clientage and financial ties of the testator, and broadens considerably our knowledge of his foundation activities or family relations.
\end{abstract}

Słowa kluczowe: Wielkie Księstwo Litewskie, Sapiehowie, kadra oficerska, awans społeczny, działalność fundacyjna

Keywords: Grand Duchy of Lithuania, the Sapiehas, officer's cadre, social advancement, foundation activity

Postać Samuela Kazimierza Kmicica, która stała się dla Henryka Sienkiewicza pierwowzorem słynnego Andrzeja - głównego bohatera Potopu, od dawna wzbudzała spore zainteresowanie historyków. Tym bardziej musi dziwić fakt, że do dzisiaj nie doczekaliśmy się żadnego większego monograficznego opracowania obejmującego wszystkie sfery działalności Kmicica. Podstawowy zasób informacji na temat jego życia niewątpliwie zawiera biogram pióra Tadeusza Wasilewskiego. Został on 
jednak napisany pół wieku temu, na podstawie bardzo skromnej bazy źródłowej i nie jest pozbawiony merytorycznych błędów ${ }^{1}$. Należy też wspomnieć, że ten sam badacz opublikował trzy popularnonaukowe artykuły, w których zamieścił sporo dodatkowych, cennych szczegółów, głównie na temat działalności wojskowej Samuela ${ }^{2}$. Tylko niewielkie wzmianki poświęcili tej postaci w swoich studiach na temat Trylogii Adam Kersten ${ }^{3}$, Marceli Kosman ${ }^{4}$ czy też Władysław Czapliński ${ }^{5}$. Najlepiej zbadaną sferę działalności Kmicica stanowi jego służba wojskowa. Jest ona udokumentowana od początku 1655 r., kiedy to Samuel - jako porucznik chorągwi kozackiej starosty żmudzkiego Jerzego Karola Hlebowicza - z pewnością wziął udział w walkach pod Mohylewem podczas nieudanej kontrofensywy armii litewskiej przeciwko oddziałom moskiewskim i kozackim ${ }^{6}$. Andrzej Rachuba opisał rolę Kmicica w zawiązaniu konfederacji wierzbołowskiej (23 VIII 1655), wypowiedzeniu przez część wojska posłuszeństwa Januszowi Radziwiłłowi po jego przejściu na stronę Szwedów i przejęciu przez żołnierzy dóbr hetmana ${ }^{7}$. W miarę dokładnie znamy również jego bardzo bogate itinerarium bojowe $\mathrm{z}$ okresu walk z Moskwą pod koniec 1655 r., a następnie ze Szwedami i Rakoczym w latach 1656-1659, w których uczestniczył jako pułkownik i rotmistrz jazdy kozackiej w dywizji prawego skrzydła hetmana wielkiego Pawła Jana Sapiehy ${ }^{8}$.

1 T. Wasilewski, Kmicic Samuel, w: PSB, t. 13, Wrocław 1967-1968, s. 81-83.

2 Idem, Pierwowzór Sienkiewiczowskiego Kmicica, „Mówią Wieki” 2, 1959, nr 4, s. 12-15; idem, Przygody pana Samuela Kmicica, pułkownika wojsk JKM w latach potopu, „Mówią Wieki” 15, 1972, nr 2, s. 5-10; idem, Wyprawy wojenne pułkownika Samuela Kmicica, chorążego orszańskiego, w latach 1659-1665, „Mówią Wieki” 16, 1973, nr 10, s. 4-9.

3 A. Kersten, Sienkiewicz - „Potop” - historia, Warszawa 1966, s. 101-102, 153, 166.

${ }^{4}$ M. Kosman, Na tropach bohaterów „Trylogii”, wyd. 5, Warszawa 1996, s. 164-170.

${ }^{5}$ W. Czapliński, Glosa do Trylogii, wyd. 2, Białystok 1999, s. 68-69.

${ }^{6}$ K. Bobiatyński, Od Smoleńska do Wilna. Wojna Rzeczypospolitej z Moskwa 1654-1655, Zabrze 2004, s. 153, 233; T. Wasilewski, Przygody pana Samuela Kmicica..., s. 5-6. W przywileju na urząd chorążego orszańskiego (z 17 IV 1658) możemy jednak przeczytać, że służba wojskowa Kmicica rozpoczęła się znacznie wcześniej - „od początku rebellijej kozackiej” i nieznanego bliżej epizodu służby w armii koronnej; Metryka Litewska. Księga wpisów nr 131, oprac. A. Rachuba, Warszawa 2001, nr 129, s. 51.

7 A. Rachuba, Konfederacje wojska litewskiego w latach 1655-1663, Zabrze 2010, s. 16-33; idem, Sprawa dóbr Radziwiłłów birżańskich w latach 1655-1662, „Miscellanea Historico-Archivistica” 7, 1997, s. 51-67.

${ }^{8}$ Poza T. Wasilewskim o udziale Kmicica w działaniach militarnych podczas drugiej wojny północnej pisali m.in.: K. Bobiatyński, Michał Kazimierz Pac - wojewoda wileński, hetman wielki litewski. Działalność polityczno-wojskowa, Warszawa 2008; A.A. Majewski, Aleksander Hilary Połubiński (1626-1679), marszałek wielki litewski. Działalność polityczno-wojskowa, Warszawa 2017; K. Marcinkowski, Stefan Czarniecki $w$ dobie potopu szwedzkiego (kampania nad Wisła i Sanem r. 1655/56), Kraków 1935; J. Płosiński Potop szwedzki na Podlasiu 1655-1657, Zabrze 2006; idem, Wyprawa kniazia Semena Urusowa na Brześć (listopad - grudzień 1655 r.), „Mazowieckie Studia Humanistyczne" 2003, nr 1-2, s. 5-31; L. Podhorodecki, Kampania polsko-szwedzka 1659 r. w Prusach i Kurlandii, „Studia i Materiały do Historii Wojskowości” 4, 1958. 
Bardzo wnikliwie zbadany został udział Kmicica w walkach $\mathrm{z}$ wojskami moskiewskimi w latach 1658-1661, kiedy to uczestniczył on w wielu ważnych starciach z nieprzyjacielem (m.in. pod Bieszenkowiczami, Połonką, nad rzeką Basią, pod Czereją i Tołoczynem)9 . Stosunkowo dużo wiemy także o aktywności pułkownika w ostatnim okresie tego konfliktu. Na początku 1664 r. na czele niewielkiego zgrupowania zabezpieczał on wschodnie ziemie Litwy podczas wyprawy wojsk Rzeczypospolitej na lewy brzeg Dniepru, kilkakrotnie doznając porażki z rąk przeciwnika. Możemy przypuszczać, że w tym samym roku uczestniczył w działaniach głównej grupy wojsk litewskich, które w czerwcu pod komendą hetmana polnego Michała Kazimierza Paca wygrały bitwę pod Witebskiem, a potem powstrzymywały znacznie liczniejsze wojska moskiewskie na linii Dniepru. Również w latach 1665-1666 Kmicic walczył w obronie ziem białoruskich, dowodząc jednym z pułków jazdy prawego skrzydła, operującym głównie w rejonie Orszy i Witebska ${ }^{10}$.

Przedmiotem zainteresowania historyków stała się również rola, jaką Samuel Kmicic odegrał w armii litewskiej na przełomie lat 50. i 60. XVII w. Dzięki badaniom Andrzeja Rachuby wiemy, że już podczas Potopu zaliczał się do grona najbardziej zaufanych oficerów Pawła Jana Sapiehy. Hetman od 1657 r. wielokrotnie korzystał z jego usług, kiedy podejmował działania mające na celu wykorzystanie wojska litewskiego do otwartych wystąpień wymierzonych w politykę króla Jana Kazimierza. W kwietniu i maju 1660 r. Kmicic stanął na czele konfederacji zawiązanej przez oddziały sapieżyńskie w Drohiczynie. Oficjalnym powodem wypowiedzenia służby przez żołnierzy były wieloletnie zaległości w wypłacie żołdu, ale przede wszystkim Sapieha chciał w ten sposób zamanifestować „potencjał opozycyjny” swojego stronnictwa, coraz bardziej zagrożonego przez rosnącą w siłę fakcję litewskich regalistów, na czele której stał kanclerz wielki litewski Krzysztof Pac. Można przypuszczać, że hetman zamierzał też wyrazić sprzeciw wobec

${ }^{9}$ Należy tutaj zwrócić uwagę przede wszystkim na liczne prace K. Kossarzeckiego: Działalność wojskowa putkownika Iwana Nieczaja na Białorusi w latach 1657-1659, „Україна в Центрально-Східній Европі" 2005, nr 5, s. 372-376; Kampania roku 1660 na Litwie, Zabrze 2005; Wojna $z$ Państwem Moskiewskim na ziemiach Wielkiego Księstwa Litewskiego w latach 1658-1661, Warszawa 2007, mps pracy doktorskiej pod kier. prof. dr. hab. M. Nagielskiego, IH UW; Кампанія 1660 году у Літве, Менск 2011; Forteca w Kopysi nad Dnieprem w latach wojny Rzeczypospolitej z Moskwa 1654-1667, „Studia z Dziejów Wojskowości” 1, 2012, s. 154-156.

${ }^{10} \mathrm{~K}$. Bobiatyński, Kampania letnia 1664 roku na terytorium Wielkiego Księstwa Litewskiego - nieznany fragment wojny Rzeczypospolitej z Moskwa 1654-1667, w: Wojsko, wojskowość, miasta. Studia poświęcone prof. Stanisławowi Herbstowi w stulecie urodzin, red. K. Bobiatyński, P. Gawron, M. Nagielski, Zabrze 2009, s. 226, 232; idem, Militarne uwarunkowania negocjacji polsko-moskiewskich w Andruszowie w latach 1666-1667, w: Studia z dziejów stosunków Rzeczypospolitej z Państwem Moskiewskim w XVI-XVII wieku, red. M. Nagielski, K. Bobiatyński, P. Gawron, Zabrze-Tarnowskie Góry 2013, s. 389, 397. Wiele miejsca poświęca tym wydarzeniom w swojej niepublikowanej rozprawie doktorskiej A. Rachuba (Wielkie Księstwo Litewskie wobec rokoszu Jerzego Lubomirskiego w latach 1664-1667, Warszawa 1979, mps pracy doktorskiej pod kier. dr. hab. T. Wasilewskiego, IH UW). 
królewskich planów elekcji vivente rege, jako stronnik Habsburgów sprzeciwiając się forsowanemu przez dwór kandydatowi francuskiemu ${ }^{11}$.

Po śmierci Pawła Jana Sapiehy Samuel Kmicic został zmuszony do odejścia z szeregów wojska, a jego chorągwie: kozacką i dragońską zlikwidowano podczas redukcji armii litewskiej przeprowadzonej przez Paców w latach 1666-1667 ${ }^{12}$. Do służby powrócił zapewne dopiero po siedmiu latach - w 1674 r., jako porucznik chorągwi husarskiej hetmana polnego Michała Kazimierza Radziwiłła. O tym okresie jego aktywności wojskowej wiemy już zdecydowanie mniej. Nie ulega wątpliwości, że uczestniczył w rozpoczętej jesienią 1674 r. kampanii na Ukrainie. Jego chorągiew brała też udział w bitwie pod Lesienicami koło Lwowa (24 VIII 1675), natomiast - podobnie jak hetman polny - Kmicic nie dotarł rok później do obozu pod Żórawno i znajdował się podczas walk z Turkami we Lwowie ${ }^{13}$. Konsekwentna postawa polityczna przyniosła w końcu upragniony awans na jeden z najważniejszych urzędów wojskowych - strażnikostwo wielkie, które Samuel otrzymał 3 lutego $1676 \mathrm{r}^{14}$

$\mathrm{Na}$ koniec warto zaznaczyć, że na początku lat 80. kariera wojskowa pułkownika zatoczyła symboliczne koło. Po śmierci najpierw Michał Kazimierza Radziwiłła, a następnie Michała Kazimierza Paca buławę polną litewską (1681), a potem wielką (1683) otrzymał Kazimierz Jan Sapieha, najstarszy syn dawnego patrona wojskowego Kmicica. Samuel niewątpliwie zaliczał się do grona jego najbliższych współpracowników, a hetman powierzył mu niezwykle prestiżowe porucznikostwo swojej chorągwi husarskiej ${ }^{15}$. O pozycji i wpływach strażnika świadczyć może fakt, że latem $1682 \mathrm{r}$. Sapieha przekazał w jego ręce na czas swojej nieobecności naczelną komendę nad całą armią litewską, dając "tak do znoszenia takich kup swawolnych potestatem [...], jako też do rozsądzenia wszelkich spraw wojskowych i do egzekucji przywiedzenia sądów swych de recentium criminum et iniuriarum"16.

11 A. Rachuba, Konfederacje..., s. 37, 41-43, 51-96.

12 J.W. Odlanicki-Poczobut, Pamiętnik (1640-1684), oprac. A. Rachuba, Warszawa 1987, Aneks 4: Komput wojska litewskiego w roku 1667, s. 344-348.

${ }^{13}$ K. Bobiatyński, Michat Kazimierz Pac..., s. 313-314; K. Bobiatyński, Z. Hundert, Skład armii Wielkiego Księstwa Litewskiego podczas wojny z Turcją (1675-1676) w świetle akt skarbowo-wojskowych, „Zapiski Historyczne” 83, 2018, nr 1, s. 163; Z. Hundert, Husaria koronna w wojnie polsko-tureckiej 1672-1676, Oświęcim 2012, s. 384-385; M. Wagner, Wojna polsko-turecka w latach 1672-1676, t. 2, Zabrze 2009, s. 288.

${ }^{14}$ Urzędnicy centralni i dostojnicy Wielkiego Księstwa Litewskiego XIV-XVIII wieku. Spisy, oprac. H. Lulewicz, A. Rachuba, Kórnik 1994, s. 191.

15 AGAD, Archiwum Zamoyskich, sygn. 3112, s. 583-586. Ostatnio dokument ten opublikował Z. Hundert, Projekty komputów wojska Wielkiego Księstwa Litewskiego z lat 1683-1684. Przyczynek do badań nad problemem rywalizacji Jana III $z$ Sapiehami o wplywy w wojsku litewskim w latach 1683-1696, „Rocznik Lituanistyczny” 3, 2017, s. 110-113.

16 LVIA, f. SA, nr 23, Uniwersał K.J. Sapiehy, Wołpa, 11 VII 1682 r., k. 929-930v. Szkoda, że niewiele na temat pozycji Kmicica w wojsku możemy się dowiedzieć z monografii stronnictwa sapieżyńskiego w interesującym nas okresie. Trudno też znaleźć dowody potwierdzające tezę, 
Znacznie mniejszym zainteresowaniem historyków cieszyła się działalność polityczna Samuela Kmicica, szczególnie w okresach, gdy nie pozostawał on w czynnej służbie wojskowej. Należy zaznaczyć, że po śmierci Pawła Jana Sapiehy pułkownik nie zmienił swojej przynależności fakcyjnej i nie przeszedł - podobnie jak duża część kadry oficerskiej dywizji prawego skrzydła - do stronnictwa pacowskiego. W kolejnych latach Kmicic blisko związał się z Michałem Kazimierzem Radziwiłłem, od 1668 r. podkanclerzym i hetmanem polnym litewskim, który podczas panowania Michała Korybuta Wiśniowieckiego stanął na czele litewskiej opozycji. Warto wspomnieć, że w 1669 r. zamierzał w orszaku księcia przybyć pod Warszawę na zjazd elekcyjny, deklarując wcześniej położyć „vitam et sanguinem przy honorze" swojego nowego patrona i popierać jego działania ${ }^{17}$.

Działalność polityczna Kmicica ograniczała się głównie do terenów, gdzie znajdowała się większość jego majętności - rodzinnego powiatu orszańskiego i sąsiedniego województwa mińskiego ${ }^{18}$. Samuel próbował odgrywać samodzielną rolę na miejscowych sejmikach, licząc na wsparcie miejscowej klienteli radziwiłłowskiej i sapieżyńskiej oraz własnego kręgu rodzinno-przyjacielskiego. O ile Mińsk w tym czasie pozostawał jednym z nielicznych bastionów przeciwników Paców, to w powiecie orszańskim znajdowali się oni w zdecydowanej defensywie. Nie ulega wątpliwości, że na początku lat 70. Kmicic nie był w stanie przeciwstawić się tutaj swoim adwersarzom, którymi energicznie kierował marszałek orszański Michał Leon Drucki Sokoliński ${ }^{19}$. Należy też zaznaczyć, że Samuel kilka razy otrzymywał mandat poselski - z sejmiku orszańskiego w $1668 \mathrm{r}$. na pewno na sejm abdykacyjny, a być może również na sejm nadzwyczajny ${ }^{20}$, w 1676 r. na sejm koronacyjny Jana III Sobieskiego i w 1681 r., a z mińskiego w 1669 r. na sejm elekcyjny ${ }^{21}$. Bliskie związki najpierw z Sapiehami, a następnie z Radziwiłłami ściągnęły za to na głowę Samuela wiele kłopotów. Od 1666 r. stał się on obiektem ostrych

że już w 1675 r. miał on zerwać swoje więzy z Radziwiłłem i powrócić na służbę Sapiehów; zob. M. Sawicki, Dom Sapieżyński 1666-1685. Droga do hegemonii w Wielkim Księstwie Litewskim, Opole 2016, s. 208.

17 AGAD, AR, dz. V, nr 4488, J. Górecki do M.K. Radziwiłła, Wilno, 14 IV 1669 r., s. 9-11; zob. też ibidem, nr 6873, S. Kmicic do M.K. Radziwiłła, Oleszkowice, 19 VII 1669 r., s. 15 (w liście tym Samuel zadeklarował podkanclerzemu, że „W czym sobie WKsM Mój Miłościwy Pan na sejmiku służyć rozkazać będziesz raczył, ochotnie wyglądać będę").

18 Aktywność Kmicica w Orszańskiem jest świetnie widoczna w świetle zachowanych materiałów sejmikowych: NGAB, f. 1875, op. 1, nr 1, k. 124, nr 2, k. 160-160v, nr 4, k. 683-690v.

${ }^{19}$ K. Bobiatyński, $W$ walce o hegemonię. Rywalizacja polityczna $w$ Wielkim Księstwie Litewskim w latach 1667-1674, Warszawa 2016, s. 64-65, 71-72, 104-105.

${ }^{20}$ Wskazuje na to Regestr posłów na sejm pro die 24 do Warszawy January A. 1668 wyprawionych (Національна бібліотека України им. В.I. Вернадського, Kijów, f. 1, nr 5953, k. 226-226v), natomiast nie wymienia Kmicica autor monografii tego sejmu; zob. M. Matwijów, Ostatnie sejmy przed abdykacją Jana Kazimierza: 1667 i 1668, Wrocław 1992, s. 178.

21 R. Kołodziej, „Ostatni wolności naszej klejnot”. Sejm Rzeczypospolitej za panowania Jana III Sobieskiego, Poznań 2014, s. 607; T. Wasilewski, Kmicic Samuel..., s. 82. 
ataków swoich nieprzyjaciól, które zdecydowanie nasiliły się w 1670 r. W sierpniu chorąży orszański został poturbowany podczas obrad komisji wojskowo-skarbowej w Grodnie, gdy podczas jednego z bankietów „zacięto go w rękę”. Zaledwie kilka tygodni wcześniej stronnicy pacowscy wykorzystali do walki z opozycją obrady Trybunału Litewskiego, doprowadzając do wydania wyroków na kilku czołowych aktywistów przeciwnej fakcji - Samuela skazano wtedy „na wieczną banicyją" ${ }^{22}$. Te opresyjne działania przyniosły zresztą zamierzony skutek, gdyż wydaje się, iż w następnych latach Kmicic znacznie ograniczył swoją aktywność publiczną. Fortuna odmieniła się dla niego dopiero w 1674 r., kiedy po elekcji Jana III Sobieskiego Pacowie zostali zmuszeni do przejścia do opozycji. Na czele nowego stronnictwa litewskich regalistów stanął wówczas szwagier monarchy i ówczesny patron Kmicica - Michał Kazimierz Radziwiłł. Jak już wspomniano, Samuel powrócił wtedy w szeregi wojska, a wkrótce doczekał się nominacji na urząd strażnika wielkiego litewskiego ${ }^{23}$.

Warto wspomnieć, że inne aspekty biografii Kmicica dotąd praktycznie pozostawały poza sferą zainteresowań historyków. W pracach Tadeusza Wasilewskiego znajdziemy tylko bardzo lakoniczne informacje na temat jego stanu majątkowego czy też powiązań finansowych. Bardzo niewiele wiemy o stosunkach rodzinnych Samuela, a praktycznie nic o jego działalności fundacyjnej. Taki stan rzeczy powinno zmienić wprowadzenie do obiegu naukowego testamentu pułkownika, który dotychczas nie został wykorzystany przez badaczy. Wydaje się, że to właśnie ten dokument najlepiej obrazuje awans społeczno-majątkowy Kmicica, który głównie dzięki długotrwałej służbie wojskowej i profitom z nią związanym z ubogiego szlachcica powiatu orszańskiego stał się dosyć zamożnym posesjonatem $^{24}$.

Akt ostatniej woli Samuela Kmicica został spisany w Wilnie 20 stycznia 1692 r., niespełna trzy miesiące przed jego śmiercią. Warto już na wstępie zwrócić uwagę, że dokument ten zawiera wiele ważnych informacji na temat powiązań klientalnych Samuela w ostatnim okresie jego aktywności. Po podziękowaniach dla swoich patronów - Kazimierza Jana i Benedykta Pawła Sapiehów - „za wszelkie dobroczynne Pańskie łaski, dobrodziejstwa i promocje", testator poprosił: „aby łaskawi byli na Dom mój”, a do swojego głównego spadkobiercy, bratanka Kazimierza Ludwika Kmicica, zaapelował, „aby się Domu Jaśnie Wielmożnych

22 J.A. Chrapowicki, Diariusz, cz. 3: Lata 1669-1673, oprac. L.A. Wierzbicki, Warszawa 2009, s. 97, 101; szerzej na ten temat zob. K. Bobiatyński, W walce o hegemonię..., s. 104-105, 208.

${ }^{23} \mathrm{Na}$ temat sytuacji wewnętrznej na Litwie w tym okresie zob. K. Bobiatyński, Stosunki Jana III Sobieskiego $z$ litewska elita władzy w pierwszym okresie rządów (1674-1676), w: Sobieski wokót spisków i konfederacji, red. M. Nagielski, Warszawa 2015 (Biblioteka Epoki Nowożytnej, t. 2), s. 129-143.

${ }^{24}$ Dobrym źródłem do badania pozycji majątkowej pułkownika są też zachowane rejestry podatkowe; zob. np. NGAB, f. 1705, op. 1, nr 24, s. 249-250; ibidem, f. 1875, op. 1, nr 2, k. 168-173v. 
Ich MMściów panów Sapiehów trzymając, onychże łaski, protekcyjej i promocyjej szukał"25.

Bardzo silna pozycja Kmicica w fakcji sapieżyńskiej wynikała nie tylko z jego zasług wojskowych i politycznych, lecz w nie mniejszym stopniu również ze środków finansowych, jakimi dysponował. Pułkownik zaczął gromadzić swój majątek jeszcze podczas Potopu, głównie przejmując (często niezgodnie z prawem) razem ze swoim bratem Janem majątki zdrajców, którzy przeszli na stronę Moskwy albo Szwedów ${ }^{26}$. Zgromadzony bardzo pokaźny kapitał od końca lat 60 . inwestował, udzielając pożyczek, czy to wileńskiej gminie żydowskiej, czy to litewskim magnatom, przede wszystkim Kazimierzowi Janowi Sapieże, który stale cierpiał na brak wolnych środków finansowych ${ }^{27}$. Dlatego też w marcu 1676 r., gdy nie mógł zwrócić Kmicicowi 11000 zł, oddał mu w dzierżawę na 3 lata majętność Oświej w województwie połockim. Z kolei w maju 1688 r. Sapieha pożyczył u Samuela i jego żony 20000 zł pod zastaw (na 2 lata) klucza Dryświaty w powiecie brasławskim, należącego do ekonomii wileńskiej ${ }^{28}$. Akurat te dwie sumy musiały zostać zwrócone przed 1692 r., gdyż nie ma o nich mowy w testamencie Kmicica ${ }^{29}$. Natomiast - jak dowiadujemy się $\mathrm{z}$ tego dokumentu - jego patron ciągle był mu wówczas winny co najmniej 32000 zł zabezpieczonych na dobrach Łuszki, Sidryczyn oraz na kamienicy w Wilnie. Znajdziemy w nim też informację, że już we wcześniejszym okresie Kmicic udzielał pożyczek finansowych swojemu pierwszemu protektorowi - zmarłemu w 1669 r. Jerzemu Karolowi Hlebowiczowi.

Przynależność fakcyjna Kmicica wpłynęła oczywiście na dobór grona osób, których obdarzył szczególnym zaufaniem, sporządzając akt ostatniej woli. Wystarczy wspomnieć, że na głównego egzekutora zapisów testamentowych wyznaczył pisarza ziemskiego wileńskiego Michała Koszczyca. Był to również zaufany sługa Kazimierza Jana Sapiehy, który - podobnie jak Kmicic - wspierał swojego protektora

${ }^{25}$ LVIA, f. SA, nr 35, k. 68v-69.

${ }^{26}$ Zob. np. Metryka Litewska. Księga wpisów nr 131.., nr 99, s. 44, nr 299, s. 93, nr 301, s. 93, nr 302, s. 93, nr 303, s. 93-94, nr 556, s. 161; T. Wasilewski, Pierwowzór..., s. 12-14. Niemałym źródłem dochodów z pewnością była dla Kmicica również arenda podatków; zob. np. NGAB, f. 1705, op. 1, nr 8, Kontrakt na arendę czopowego województwa brzeskiego na okres dwóch lat za sumę 6000 zł, Brześć, 6 VIII 1661 r., s. 596-598.

27 Jako ciekawostkę można podać fakt, że w 1675 r. pożyczkę u Kmicica w wysokości 2600 zł wzięło nawet towarzystwo chorągwi tatarskiej Michała Kazimierza Radziwiłła, pod zastaw wsi Kurowszczyzna w powiecie orszańskim, którą niegdyś otrzymało od J.K. Hlebowicza; zob. NGAB, f. 1875, op. 1, nr 4, Zeznanie Selima Abrahimowicza i Józefa Tupalskiego, rotmistrza i porucznika tej jednostki, Nieśwież, 7 VII 1675 r., k. 701-702v.

${ }^{28}$ LVIA, f. SA, nr 15, k. 481-482v; ibidem, nr 31, k. 305-306v, 307-308v; zob. też M. Sawicki, op. cit., s. 208.

29 Znamy też nazwiska kolejnych dzierżawców obydwu majętności. 14 I 1692 r. Sapieha oddał w zastaw Dryświaty wojskiemu wileńskiemu Bogusławowi Gimbutowi, natomiast 22 IV 1692 r. generałowi artylerii litewskiej Mateuszowi Romerowi; LMAVB, f. 18, nr 120, s. 770. W sprawie Oświei zob. kolejny przypis. 
licznymi pożyczkami pieniężnymi ${ }^{30}$. Natomiast pieczętarzami zostali: Fortunat Zamoyski - ekonom generalny dóbr hetmana wielkiego, a poza tym oficerowie armii litewskiej i wieloletni towarzysze broni testatora - Stanisław Popławski oraz Kazimierz Michał Pusłowski. Co warto podkreślić, obaj służyli w różnych okresach jako chorążowie w chorągwiach husarskich, których porucznikiem był strażnik wielki litewski, a oprócz tego można ich niewątpliwie zaliczyć do kręgu najważniejszych klientów wojskowych Kazimierza Jana Sapiehy.

Testament zawiera także kilka interesujących informacji na temat rodziny Samuela Kmicica i stosunków w niej panujących. Tadeusz Wasilewski podawał, że pułkownik miał dwie żony. Niestety nie znamy ani imienia, ani nazwiska pierwszej z nich. O drugiej wiemy, że zmarła przed sporządzeniem ostatniej woli przez małżonka. Była nią poślubiona ok. 1676 r. Anna Kantakuzen, pochodząca z greckiej rodziny osiadłej w Rzeczypospolitej, wdowa najpierw po Hieronimie Korsaku Zaleskim, a następnie Albrychcie Konstantym Ciechanowieckim ${ }^{31}$. Samuel Kmicic z całą pewnością nie pozostawił po sobie własnego potomstwa, choć takie informacje czasami pojawiają się w literaturze historycznej ${ }^{32}$. Na swoich spadkobierców wyznaczył dzieci brata Jana i Anny z Olizarów Wołczkiewiczów Kazimierza Ludwika, Adama i Katarzynę. Co ciekawe, w swoim testamencie nie wspomina zupełnie o licznym potomstwie swojej żony z jej poprzedniego małżeństwa, która ze związku z Ciechanowieckim doczekała się co najmniej siedmiorga dzieci. W nieodległej przyszłości doprowadziło to zresztą do licznych konfliktów pomiędzy nimi a Kazimierzem Ludwikiem Kmicicem, któremu Samuel przekazał prawa do majątku odziedziczonego po zmarłej małżonce ${ }^{33}$.

Głównym sukcesorem strażnika litewskiego został Kazimierz Ludwik Kmicic. Już wcześniej cieszył się on szczególnymi względami Samuela. Z pewnością to dzięki jego protekcji już w 1688 r. młodzieniec służył jako towarzysz w jednej $\mathrm{z}$ najbardziej prestiżowych jednostek całej armii litewskiej (wtedy w kompucie

${ }^{30}$ Np. w 1685 r. Sapieha pożyczył u niego 25300 zł pod zastaw Oświei i nieznaną sumę pod zastaw dóbr Siennice w województwie witebskim; LVIA, f. SA, nr 27, k. 65-66v, 67-68v.

${ }^{31}$ Dzieje rodziny Ciechanowieckich herbu Dąbrowa (XIV-XXI wiek), wyd. H. Lulewicz, A. Rachuba, J. Sikorska-Kulesza, S. Dumin, A. Haratym, A. Macuk, A. Pospiszil, red. A. Rachuba, Warszawa 2013, s. 118-119.

32 T. Wasilewski, Kmicic Samuel..., s. 82. W biogramie Kmicica błędnie podano, że miał on syna Kazimierza (w rzeczywistości bratanka), a jego córka zapewne była żoną pisarza wielkiego litewskiego Michała Leona Druckiego Sokolińskiego. W rzeczywistości dygnitarz ten miał trzy żony: Annę Galimską, Annę Kozieł Poklewską i pasierbicę Kmicica - Helenę Ciechanowiecką, a ostatnie małżeństwo chyba nie należało do udanych; zob. AGAD, AR, dz. V, nr 6874, A. Kmicicowa do A.H. Połubińskiego, 25 XII 1678 r., s. 1; A. Rachuba, Sokoliński (Drucki Sokoliński) Michał Leon, w: PSB, t. 40, Warszawa-Kraków 2000-2001, s. 48. Warto zaznaczyć, że zgodne z prawdą informacje na temat powiązań rodzinnych Samuela podał już A. Boniecki, Herbarz polski, t. 10, Warszawa 1907, s. 187.

33 Dzieje rodziny Ciechanowieckich..., s. 118, 140, 144-145, 149; zob. też LVIA, f. SA, nr 14, Testament A.K. Ciechanowieckiego, Wilno, 23 III 1674 r., k. 363-366v. 
była też królewska chorągiew husarska) - chorągwi husarskiej hetmana wielkiego, w której - jak pamiętamy - jego stryj był porucznikiem ${ }^{34}$. W tym samym roku strażnik litewski scedował mu również starostwo krasnosielskie. Na mocy testamentu Kazimierz otrzymał wszystkie majętności ziemskie testatora, na czele z jego główną rezydencją - Horodnią (Horodnicą) w powiecie orszańskim, prawo do 46000 zł zapisanych na różnych dobrach, jak też dwory stryja w Wilnie i Orszy oraz większość jego dóbr ruchomych.

Zdecydowanie mniejszą część majątku otrzymali Adam Kmicic i Katarzyna Kmicicówna, po mężu Rozwadowska. Oboje dostali po 2000 zł wierzytelności, które stryjowi był winny Kazimierz Jan Sapieha, a Adam dodatkowo pewne sumy w gotówce i kilka „ruchomości” stryja. Pominięcie drugiego z bratanków w podziale majętności wynikało z pewnością z faktu, że już w 1681 r. wstąpił on do zakonu jezuitów. Warto wspomnieć, iż zrobił w nim całkiem interesującą karierę. W latach 1687-1691 odbył studia teologiczne w Rzymie, a po powrocie był profesorem filozofii w kolegium jezuickim w Warszawie (1692-1694), a następnie filozofii (1697-1700) i teologii moralnej (1700-1702) na Akademii Wileńskiej. Poza tym pełnił też funkcje spowiednika nuncjusza Andrei Santa Croce oraz opiekuna Sodalicji Mariańskich ${ }^{35}$.

Należy w tym miejscu zaznaczyć, że w testamencie Samuela Kmicica znajdujemy sporo zapisów wskazujących na to, iż również sam pułkownik miał bardzo bliskie związki z tym zakonem. Przede wszystkim na miejsce swojego pochówku wybrał wileński kościół pw. św. Ignacego Loyoli. Świątynia ta, położona pomiędzy ulicami św. Ignacego, Benedyktyńską i Tatarską, została wybudowana w latach 1622-1647, konsekrowana zaś 21 lipca 1647 r., na potrzeby nowicjatu jezuickiego prowincji litewskiej ${ }^{36}$. Warto też wspomnieć, że to właśnie na kościół św. Ignacego testator przekazał w akcie swojej ostatniej woli dwa największe legaty, ogółem na sumę 10000 zł na modlitwy za swoją duszę, a także kilka mniejszych donacji. Natomiast w budynku nowicjatu wileńskiego zdeponował dużą część środków pieniężnych i ruchomości (broń i różne sprzęty wojenny, ubrania), co niewątpliwie świadczy o szczególnym zaufaniu, jakim obdarzał to zgromadzenie.

Akt ostatniej woli wyraźnie pokazuje, że ważnym elementem duchowości Kmicica był też bardzo popularny w tym czasie w Rzeczypospolitej kult maryjny. Samuel otaczał Matkę Boską szczególną czcią, uważał za swoją patronkę i opiekunkę, a także wierzył, że to właśnie Jej opiece zawdzięczał wyjście z życiem z tylu niebezpieczeństw wojennych.

Pomimo tego wydaje się, że Samuel Kmicic był przede wszystkim twardo stąpającym po ziemi żołnierzem, który wolał inwestować swoje środki finansowe

${ }^{34}$ RGADA, f. 389, nr 142, s. 403-405.

35 Encyklopedia wiedzy o jezuitach na ziemiach Polski i Litwy 1564-1995, oprac. L. Grzebień, Kraków 1996, s. 285.

36 J. Paszenda, Budowle jezuickie w Polsce: XVI-XVIII w., t. 4, Kraków 2010, s. 393-405. 
w kupno nieruchomości czy też pożyczki niż przeznaczać je na fundacje religijne albo mecenat kulturalny. $Z$ pewnością jego głównym celem było pozostawienie dla spadkobierców trwałych podstaw materialnych, które potwierdzałyby awans społeczny następnych pokoleń rodziny Kmiciców, niż kosztownych dzieł sztuki, mających chociażby upamiętniać własne dokonania na polu wojskowym. Analiza testamentu wyraźnie pokazuje, że działalność fundacyjna Samuela była bardzo skromna. Testator wspomina tylko o wybudowaniu i wyposażeniu cerkwi w swojej wsi Moszkowo w powiecie orszańskim, którą polecił opiece głównego sukcesora. Jednak środki przeznaczone na utrzymanie tego budynku - zaledwie $10 \mathrm{zł} \mathrm{rocz-}$ nie - świadczą, że musiała to być bardzo skromna fundacja. Legaty testamentowe pozwalają też przypuszczać, iż Kmicic wspierał finansowo zarówno kościoły i zakony w Orszy, jak również kościół w Krasnym Siele - siedzibie nadanego mu przez Jana Kazimierza starostwa w województwie mińskim.

Testament strażnika wielkiego litewskiego Samuela Kmicica został przedstawiony przed sędziami Trybunału Głównego Litewskiego przez Aleksandra Hordziejewskiego $^{37}$, a następnie wpisany do akt trybunalskich 26 kwietnia 1692 r. Dzisiaj księgi te przechowywane są w Archiwum Historycznym Państwa Litewskiego (Lietuvos valstybès istorijos archyvas) w Wilnie. Do aktu ostatniej woli pułkownika dołączono dwa dodatkowe dokumenty. Zostały one również objęte niniejszą edycją, gdyż tworzą integralną całość z właściwym tekstem testamentu, a poza tym niewątpliwie stanowią bardzo cenne źródło do badań nad różnymi aspektami biografii Kmicica. Pierwszy z nich, tzw. additament, zawiera przede wszystkim dodatkowe wytyczne dotyczące wysokości legatów pieniężnych przeznaczonych dla poszczególnych osób z bliskiego kręgu testatora, kilku zakonów i szpitali. Znalazły się tutaj również szczegółowe dyspozycje w kwestii podziału niektórych cenniejszych „ruchomości”, jak też przyszłości dworku Kmicica w Wilnie.

Drugi z dokumentów powstał 4 kwietnia 1692 r., a więc dwa i pół miesiąca po spisaniu testamentu. Co ważne, jest to ostatni znany akt sygnowany własnoręcznie przez Samuela Kmicica. Pozwala to z dużo większą dokładnością określić datę jego śmierci, która z całą pewnością miała miejsce przed 13 kwietnia ${ }^{38}$. Dokument ten zawiera rejestr służby i czeladzi wojskowej pułkownika, pozostającej na jego utrzymaniu i teraz dodatkowo uhonorowanej przez swojego chlebodawcę (sumami pieniężnymi, ubraniami albo suknem). W spisie tym zostało ujętych z imienia albo nazwiska 21 osób, nie uwzględniono natomiast „czeladzi drobniejszej folwarkowej”. Źródła tego nie mógł w żadnym wypadku znać Henryk Sienkiewicz, gdy kreślił na kartach Potopu obraz słynnej „kompanii Kmicicowej”. Stosunkowo najbardziej przyjemną postacią z całej bandy miał być niejaki pan

\footnotetext{
37 Z pewnością chodzi tu o Aleksandra Michała Hordziejewskiego (zm. ok. 1711), miecznika wileńskiego w latach 1694-1710.

${ }^{38}$ LVIA, f. SA, nr 35, k. 25-26v, 74-75v.
} 
Rekuć-Leliwa, „na którym krew nie ciężyła, chyba nieprzyjacielska. Fortunę on za to w kości przegrał i przepił - od trzech lat przy panu Kmicicu się wieszał"39. Co ciekawe, wśród służby Samuela Kmicica znajdowało się aż dwóch panów Rekuciów - starszy i młodszy (być może ojciec i syn), a ten drugi dostał nawet od swojego pryncypała "na szkoły złotych 40 ”.

\section{Aktykacja testamentu w Bogu zeszłego Wielmożnego JMści pana Kmicica strażnika WKsL, Wilno, 20 I 1692 r.}

Podstawa wydania: LVIA, f. SA, nr 35, k. 61-72v

W imię Boga Ojca, w Trójcy Świętej jedynego Amen! Z wszechmocnej Niebieskiego Twórcy Opatrzności, snadnie każdy codzienną może dochodzić eksperiencyją, że wszytkie kreatury wielowładną Jego uczynione ręką są znikome i doczesne, a nic pewniejszego na tym świecie nad śmierć, że każdy żyjący człowiek nie tylko w chorobie będący, ale by w największej fortunie i w najsposobniejszym zostając zdrowiu, zamierzonego sobie nie może wiedzieć kresu, kiedy i którego momentu, Najwyższy Sędzia przed trybunał swój stawać i ze wszytkiego liczbę i rachunek dać każe. Zaczym jako duszy nic nad to pożyteczniejszego, tak i skazitelnemu ciału nic lepszego, jako gdy człowiek w sumnieniu swoim z Panem Bogiem ma swe porachowanie i w powierzonych sobie od tegoż Pana dobrach, porządną po sobie zostawi dyspozycyją. Za którą takowy w przemienieniu swym $\mathrm{z}$ tego doczesnego żywota do onej nieskończonej odchodzący wieczności, pożądany pokój i nieśmiertelną sławę na potomne zostawuje wieki.

Przeto ja Samuel Kmicic strażnik WKsL, będąc niesposobnego zdrowia, jednak przy zmysłach, rozumie i doskonałej pamięci zostając, a oglądając się na odmienność czasu, a za tym nieuchronionej strzeż Boże libityny ${ }^{40}$, wprzód rachując się w sumnieniu z Twórcą i Bogiem moim, od którego wszytkie nie tylko doczesne dobra, ale i najprzedniejszy talent duszę nieśmiertelną mając, one w ręce tegoż Najwyższego Pana, w zasługę i przeważną przyczynę Matki Jego Królowej Niebieskiej Przenajświętszej Panny Mariej, Paniej i opiekunki mojej (którejem obrony i łaski za życia mego doznawał i w różnych przygodach a srogich prawie razach moich byłem od Niej piastowany). Tudzież Aniołom Bożym i wszytkim Świętym Patronom moim poruczam i oddaję, dobrą wiarę, nadzieję i ufność w Miłosierdziu Boskim mając, że duszę moję do onej Korony wiekuistej Królestwa nieskończonego, w chwale swej świętej przyjąć będzie raczył. Ciało zaś moje grzeszne, bez wszelkiej pompy światowej, obrzędem Kościoła Świętego Rzymskiego, w kościele św. Ignacego w Wilnie będącym, na miejscu na to naznaczonym

\footnotetext{
39 H. Sienkiewicz, Potop, t. 1, Warszawa 1968, s. 26.

${ }^{40}$ Libityna - rzymskie bóstwo czuwające nad właściwym przebiegiem ceremonii pogrzebowych.
} 
złożone być ma. Na który to kościół 8000 złotych polskich w talarach bitych, na szkole żydowskiej wileńskiej ${ }^{41}$ lokowane zapisuję, aby Ich MM Ojcowie Jezuici nowicjatu wileńskiego ${ }^{42}$, według świątobliwego institutum swego Pana Boga za duszę moję prosili. Osobliwie 2000 złotych polskich także w talarach bitych na tejże szkole żydowskiej będące leguję, aby za duszę moję dwie mszy święte czytane na każdy tydzień w tymże kościele odprawowane były, to jest jedna w piątek przez krucyfiksem, a druga w sobotę u ołtarza Najświętszej Panny; co wszytko w zapisie ode mnie pomienionym Ojcom danym, jest szyrzej wyrażono. Item sumę moję 2000 złotych polskich, na tejże szkole żydowskiej wileńskiej będącą, za duszę moję tak rozdzielam: Ich MMściom Ojcom Bernardynom konwentu wileńskiego 1000 złotych, Ich MMściom Ojcom Franciszkanom wileńskim drugi 1000 złotych, ażeby coroczna kwota od tej sumy przychodząca na msze święte obrócona była, według danych od tychże Ich MMściów księży Bernardynów i Ich MMściów księży Franciszkanów zapisów. Majętność moję wieczystą Horodnica nazwaną, $\mathrm{w}$ powiecie orszańskim leżącą, ze wszytką należytością, $\mathrm{z}$ sprzętem domowym, cyną, miedzią, z stadem bydłem rogatym i nierogatym i ze wszytkiemi rzeczami, JMści panu Kazimierzowi Kmicicowi ${ }^{43}$ staroście krasnosielskiemu ${ }^{44}$ tym testamentem wiecznie zapisuję, z tym jednak obowiązkiem, aby z pierwszorocznej intraty pieniężnej, która po żywocie moim będzie przychodziła, z tej i inszych majętności i wiosek w tymże powiecie będących, za duszę moję na kościoły orszańskie, to jest Ich MMściów Ojców Bernardynów, Ich MMściów Ojców Dominikanów, Ich MMściów Ojców Franciszkanów i Ich MMściów Ojców Jezuitów, po złotych 30 rozdał, także i na szpitale orszańskie według liczby ubogich. Folwark Oskryszenie z przynależnościami do tegoż folwarku należącemi Jelin i Dubrowki nazwanemi, prawem zastawnym od JMści pana Mikołaja Ciechanowieckiego, po tym wojewody mścisławskiego ${ }^{45}$, w 5000 u mnie zostawiony,

${ }^{41}$ Chodzi tutaj o synagogę wileńską, której budynek pod koniec XVII w. znajdował się na ul. Żydowskiej. Użyta tu formuła oznacza, że Kmicic udzielał pożyczek gminie żydowskiej, zapewne na bardzo korzystnych dla siebie warunkach (dla szlachty oprocentowanie wynosiło z reguły około $10 \%$ rocznie).

${ }^{42}$ Nowicjat wileński dla litewskiej prowincji jezuitów był czynny od 1604 r., a jego dom znajdował się pomiędzy ulicami Tatarską i św. Ignacego, w sąsiedztwie kościoła św. Ignacego; J. Paszenda, op. cit., s. 393-394, 401-402.

${ }^{43}$ Kazimierz Ludwik Kmicic (zm. 1703), syn Jana Kmicica i Anny Olizarówny Wołczkiewiczówny, pod koniec życia wójt i podstarości orszański.

${ }^{44}$ Krasne Sioło - starostwo w województwie mińskim, na które Samuel Kmicic otrzymał przywilej 18 I 1656 r.; Metryka Litewska. Księga wpisów nr 131..., nr 169, s. 61.18 III 1672 r. w Warszawie scedował te dobra swojemu bratankowi Adamowi Kmicicowi, a następnie (zapewne w następstwie wstąpienia tegoż do zakonu jezuitów) 23 IV 1688 r. w Wilnie - jego bratu Kazimierzowi Ludwikowi; RGADA, f. 389, op. 1, nr 137, k. 17-18v, nr 142, s. 403-405.

${ }^{45}$ Mikołaj Walerian Ciechanowiecki (zm. 1672), wojewoda mścisławski od 1659 r. Folwark Okrosieńce (Okresienie) ze wsiami Jelino i Dubrowka zostały zastawione przez niego Kmicicowi 13 IV 1653 r., początkowo na 3 lata, na sumę 4500 zł; Dzieje rodziny Ciechanowieckich..., s. 101. 
w powiecie orszańskim leżący, ze wszytkim bydłem i ruchomością folwarkową, temuż JMści panu synowcowi memu zapisuję. Osobliwie wieś Szemberów w tymże powiecie orszańskim leżącą, we 3000 złotych dobrej monety zastawną, tudzież Kułakowszczyznę przez mię wiecznością kupioną, z sprawami i należytościami onych onemu leguję. Dwór mój własny w mieście orszańskim będący, z innemi domami i placami mnie należącemi, temuż synowcowi memu wiecznie zapisuję. Czerkasów i Puzyrów w powiecie orszańskim leżące, własność Ich MMściów księdza Adama Kmicica Societatis Jesu ${ }^{46}$ i pana Kazimierza Kmicica synowców moich i paniej Katarzyny Kmicicówny Rozwadowskiej siostry Ich MMściów, jako rodzicowi onych, a rodzonemu memu JMści panu Janowi Kmicicowi stolnikowi orszańskiemu ${ }^{47}$ należała, tak $\mathrm{w}$ całości zostająca, tymże pomienionym Ich MMściom według naturalnego prawa należeć ma. Co się tknie Kamionki, Łańcowa, Dubniej od Jaśnie Wielmożnych JMści pana Jerzego Karola Hlebowicza wojewody wileńskiego ${ }^{48}$ i samej Księżnej JejMść paniej Katarzyny Radziwiłłówny ${ }^{49}$ małżonków, w zastawie u mnie będących, w powiecie orszańskim, w zastawie u mnie będących, od Jaśnie Wielmożnego JMści pana Kazimierza Sapiehy wojewody wileńskiego ${ }^{50}$ folwarku Siedryczyna ${ }^{51}$, który w 9000 jest zastawiony, za odebraniem z pełna tych 9000 i za oddaniem za przybudynki, co Ich MM panowie przyjaciele uznają, synowiec mój tych zaś wsi pomienionych ustąpić i wszytkie prawa do nich należące oddać ma; którą tą sumę temuż JMści panu synowcowi memu zapisuję. Wieś moję Moszkowo w tymże powiecie orszańskim leżącą i grunty niektóre prawem wieczystym, niektóre prawem zastawnym nabyte, do mnie należące, na co są pewne dokumenta w skarbcu horodnieńskim złożone, według których pomieniony JM pan synowiec mój ma się sprawić, onemuż zapisuję. Cerkiew przez mnie nowo $\mathrm{w}$ tejże wsi wybudowana (do której wszytkie aparaty posprawowałem), żeby w opatrzeniu dobrym była w niej chwała Boża nie ustawała, tegoż JMści pana synowca mego proszę, przydając to, ażeby co rok po złotych $10 \mathrm{z}$ karczmy pomienionej wsi Moszkowo do tejże cerkwi na świece i wino dawano obowiązuję. Wieś Kluczników, ponieważ wszytkie ciężary poznosiłem z niej, temuż synowcowi memu zapisuję i prawa wszytkie nabyte $\mathrm{w}$ tejże

46 Adam Stanisław Kmicic (zm. 1702), syn Jana Kmicica i Anny Olizarówny Wołczkiewiczówny, wstąpił do zakonu jezuitów w lipcu $1681 \mathrm{r}$.

${ }^{47}$ Jan Kmicic (zm. po 1662) był porucznikiem chorągwi kozackiej Samuela.

48 Jerzy Karol Hlebowicz (zm. 1669), wojewoda wileński w latach 1668-1669.

49 Katarzyna z Radziwiłłów Hlebowiczowa (zm. 1674), od 1640 r. żona Jerzego Karola.

${ }^{50}$ Kazimierz Jan Sapieha (zm. 1720), wojewoda wileński od 1682 r., hetman wielki litewski od $1683 \mathrm{r}$.

${ }^{51}$ Starostwo sidryczyńskie w powiecie orszańskim po śmierci Hlebowicza otrzymał w 1670 r. jeden z jego zięciów - Marcjan Ogiński; LVIA, f. SA, nr 11, k. 796-797v. Zapewne po jego śmierci w 1690 r. dobra te przeszły w ręce Sapiehy, który oddał je w zastaw Kmicicowi. Po zgonie Samuela pozostały nadal w rękach rodziny Kmiciców - najpierw Kazimierza Ludwika, a następnie jego syna Jana; Dzieje rodziny Ciechanowieckich..., s. 163. 
majętności Horodnie będące, na tęż wieś służące do rąk oddaję. Kamienicę moją w Wilnie na wileńskiej ulicy będącą, od Jaśnie Wielmożnego JMści pana wojewody wileńskiego z restauracyją we 3000 zastawną, za odebraniem z pełna tej sumy synowiec mój ustąpić $\mathrm{ma}^{52}$; którą sumę temuż synowcowi memu zapisuję. O majętności mojej Łuszkach w województwie połockim leżącej, od Jaśnie Wielmożnego JMści pana Kazimierza Sapiehy wojewody wileńskiego i samej JeJMść paniej wojewodzinej wileńskiej we $20000 \mathrm{u}$ mnie zastawnej ${ }^{53}$, tak rozporządzam: z tejże sumy JMści panu Kazimierzowi Kmicicowi staroście krasnosielskiemu 16000 złotych polskich, JMści księdzu Adamowi Kmicicowi Societatis Jesu 2000 złotych polskich, JeJMść paniej Katarzynie Kmicicównie Rozwadowskiej 2000 złotych polskich zapisuję, a do oddania tej sumy pomienionej majętności JM pan Kazimierz Kmicic synowiec mój za prawem mnie danym, dzierżącym być ma. Sumę zaś moję na majętności Podbrzezie w województwie wileńskim leżącej, przy dożywociu od zeszłej małżonki mojej 10000 złotych mnie zapisaną ${ }^{54}$, temuż synowcowi memu zapisuję i prawa moje nań wlewam. Inne sumy wszytkie moje, tak na majętności Dąbrowie, jako też i w nowicjacie wileńskim Societatis Jesu zostające, do dalszej mojej dyspozycyjej zachowuję, okrom legowanych na różne kościoły, które bez żadnej dilacyjej zaraz po zejściu moim mają być oddane według woli mojej w additamencie wyrażonej. Z pomienionej zaś sumy w nowicjacie zostającej, 500 złotych polskich na kościół krasnosielski leguję, aby za duszę moję na pomienionym miejscu teraźniejszy JM ksiądz pleban i successorowie JMści Pana Boga prosili i mszą świętą jednę czytaną w tydzień odprawili. Item za duszę moję na kościoły orszańskie, to jest na kościół Ich MMściów Ojców Bernardynów, Dominikanów, Franciszkanów i Jezuitów po złotych 500 z sumy mojej leguję; która to suma osobliwie będzie specyfikowana. Na msze zaś święte do kościołów wileńskich zapisuję złotych 1425, które tak mają być rozdane: do kościoła św. Stanisława w zamku złotych 100, do św. Jana złotych 100, do Ojców Dominikanów u św. Ducha złotych 100, do Ojców Franciszkanów złotych 100, do Ojców Bernardynów złotych 100, do Ojców Karmelitów Wszytkich Świętych złotych 100, do Ojców Karmelitów Bosych złotych 100, do św. Kazimierza złotych 100, do Ojców Karmelitów św. Jerzego złotych 50, do św. Piotra na Antokolu

52 Sapieha rzeczywiście od razu po śmierci Kmicica przejął tę nieruchomość, aby już 13 IV 1692 r. przekazać ją w dożywotnią dzierżawę innemu swojemu zaufanemu słudze, skarbnikowi różańskiemu Teodorowi Berniczowi, „respektując na JMści życzliwe Domowi naszemu wyświadczone usługi”; LVIA, f. SA, nr 35, k. 25-26v.

${ }^{53}$ Dobra te, należące do majętności Ikaźń, Kmicic otrzymał od Sapiehy prawem dożywotnim 23 IV 1686 r. - jak podkreślono w przywileju - w nagrodę za "tak Dobrodziejom Rodzicom Naszym, jako i Nam samym [na] Marsowym Polu, jako też in publicis consiliis szczyre affekta i przyjaźń"; LVIA, f. SA, nr 28, k. 121-124v.

54 Żoną Kmicica była Anna z Kantakuzenów (zm. ok. 1691). Dobra Podbrzezie alias Polipie otrzymała ona od swojego poprzedniego męża, oboźnego litewskiego Albrychta Konstantego Ciechanowieckiego; Dzieje rodziny Ciechanowieckich..., s. 118. 
złotych 100, do Ojców Dominikanów u św. Jakuba złotych 100, do Ojców Bazylianów u św. Trójcy złotych 50, do Ojców Augustianów na Sawicz ulicy złotych 50, do Ojców Dominikanów w Werkach złotych 50, do Księży Misjonarzów złotych 50, do Ojców Bonifratelów złotych 50, do św. Katarzyny złotych 50, do Ojców Augustianów na Zarzeczu złotych 30, do św. Stephana złotych 15, do św. Trójcy przy Dominikanach złotych 15, do św. Nikodema złotych 15. Co wszytko zaraz po zejściu moim ma być rozdano. Do kościoła zaś św. Ignacego na świece jarzące do ołtarzów i na wino do mszy świętych przy złożeniu ciała mego, naznaczam złotych 500. A pomienione sumy do dalszej dyspozycyjej mojej zachowane, według regestru ode mnie podpisanego rozdane być mają, tak jako się wyrazi w additamencie do tegoż testamentu przydanym. Sprzęt mój i wszytkę ruchomość, tak u Ich MMściów Ojców Jezuitów nowicjatu wileńskiego, jako i w pomienionej kamienicy mojej złożoną, to jest złoto, srebro, rządy, rządziki, wsiądzenia, rynsztunki wojenne, szaty i różne ochędostwa, podług regestrów ręką moją podpisanych, u JMści pana Michała Koszczyca pisarza ziemskiego wileńskiego ${ }^{55}$ jako egzekutora, a przeciwnych rejestrów w każdej skrzyni złożenia będących, temuż JMści panu Kazimierzowi Kmicicowi synowcowi memu zapisuję, excepto osobliwego regestru także ręką moją podpisanego, według którego z pomienionego sprzętu pewnym Ich MMściom panom krewnym moim niektóre rzeczy leguję. Co aby się wszytko według woli mojej stało, upraszam tegoż JMści pana pisarza ziemskiego wileńskiego. Wszytkie zaś pomienione rzeczy aż do rozdania mają zostawać u JMści księdza Adama Kmicica Societatis Jesu synowca mego, do których rzeczy i klucz u JMści zostawuję. Sługom moim i czeladzi drobniejszej (z których niepotrzebnych, zaraz im popłaciwszy, odprawić) według regestru mego podpisanego, co któremu leguję, w cale oddano być ma. Item czeladzi folwarkowej po porachowaniu się, co im urzędnicy dali, a co zatrzymali, w całości ciż sami urzędnicy z folwarku oddać mają; których to urzędników pomienieni Ich MM panowie egzekutorowie ze wszytkiego przez wszytkie lata nieodebranej liczby stricte słuchać mają. Ażeby JM pan Kazimierz Kmicic starosta krasnosielski synowiec mój jakowej post fata mea od kogo nie miał turbacyjej, tym testamentem moim objaśniam, iż żadnych długów przez mię jakowymkolwiek sposobem zaciągnionych nie mam i żadna majętność moja nie jest pienna, okrom jednego obligu JMści panu Łyszkiewiczowi sekretarzowi JKMści ${ }^{56}$ na 2000 złotych; w taki sposób danego, iż za dojściem zasług z skarbu Rzeczypospolitej ten oblig miałem od JMści rekuperować. Atoli respektując na życzliwość JMści ku mnie, nie z skarbu odebranych pieniędzy, ale z mojej własnej intraty złotych 1000 Ich MM panowie egzekutorowie aby oddali i pomieniony skasowali

${ }^{55}$ Michał Koszczyc (zm. ok. 1709), pisarz grodzki wileński w latach 1682-1688, a od 1688 r. pisarz ziemski wileński.

${ }^{56}$ Michał Łyszkiewicz (zm. 1695), sekretarz JKM, wiceregent kancelarii mniejszej litewskiej od 1690 r., stolnik orszański od 1691 r. 
oblig, naznaczam. Za innemi zaś kartami mojemi (za któremi nie rozumiem, aby nad złotych 300 wyniosło), ciż Ich MM panowie egzekutorowie wypłacić mają, nie obciążając duszy mojej, których to obligów regestr z podpisem ręki mojej zostawuję. Zasług zaś moich u skarbu Rzeczypospolitej zaległych, synowiec mój dochodzić ma, wespół z towarzystwem znaku mego i jako deputatami, z JMścią panem Szmatowiczem i JMścią panem Florianem Nowoszyńskim; których doszedłszy, a osobliwie z miliona, towarzystwu chorągwi moich podług zasług i dokumentów płacić ma ${ }^{57}$. A których by w żywocie nie stawało, tedy znosząc się z Ich MMściami panami wyż pomienionemi deputatami, na kościoły i ubogich rozdać powinien będzie, żadnego nie przepominając. Co się też kolwiek w tym testamencie moim z pewnych natenczas przyczyn nie objaśniło i cokolwiek do wolnej mojej zostawiłem dyspozycyjej, to wszystko additamentem do tegoż testamentu należącym, na piśmie ostatniej woli mojej rozporządzę. Który to additament za równo $\mathrm{z}$ testamentem moim akceptowany być ma i w tymże walorze zostawać, jako i testament sam. Przy tym wszytkim, co się JMści panu Kazimierzowi Kmicicowi synowcowi memu zapisało, tenże synowiec mój zostawać ma. Którego aby na duszę moję zawsze pamiętał, sumnieniem obowiązuję i proszę, aby żadnemu w tym testamencie nie przeczył punktowi. Za protektorów i osobliwych dobrodziejów temuż synowcowi memu proszę Jaśnie Wielmożnego JMści pana Kazimierza Sapiehy wojewody wileńskiego, hetmana wielkiego WKsL i Jaśnie Wielmożnego JMści pana Benedykta Sapiehy podskarbiego i pisarza ziemskiego WKsL ${ }^{58}$, którym dziękując za wszelkie dobroczynne Pańskie łaski, dobrodziejstwa i promocje, proszę aby łaskawi byli na Dom mój i JMści pana Kazimierza Kmicica synowca mego, którego proszę, upominam i obowiązuję, aby się Domu Jaśnie Wielmożnych Ich MMściów panów Sapiehów trzymając, onychże łaski, protekcyjej i promocyjej szukał. Tudzież za protektora i Jaśnie Wielmożnego JMści pana Aleksandra Woyny kasztelana nowogródzkiego ${ }^{59}$ upraszam, za egzekutora zaś temu testamentowi memu JMści pana Michała Koszczyca pisarza ziemskiego wileńskiego i JMści pana Kurosza skarbnika smoleńskiego ${ }^{60}$ proszę, obowiązując Ich MMściów surowym sądem i dekretem Boskim, aby we wszytkim woli mojej dosyć czyniąc, co komu tym testamentem leguję i co osobliwym additamentem

57 Chodzi tutaj głównie o zaległości w stosunki do dawnej chorągwi kozackiej Kmicica (zob. rachunki tej jednostki, które sporządzono na komisjach wojskowo-skarbowych w latach 1662 -1671: LVIA, f. SA, nr 3414, k. 342v-343v; ibidem, nr 3418, k. 209v; ibidem, nr 4106, k. 11-13; ibidem, nr 4111, k. 50-50v; ibidem, nr 4114, k. 25v). Jeszcze w 1676 r. dług skarbu litewskiego wobec Samuela wynosił 8000 zł, z czego 6000 zł zabezpieczono na starostwie krasnosielskim, natomiast reszta miała zostać spłacona z uchwalonych wówczas podatków. Jak jednak widać, sumy tej Kmicic nie odzyskał w całości do końca życia; Volumina legum, t. 5, wyd. J. Ohryzko, Sankt Petersburg 1860, s. 217.

58 Benedykt Paweł Sapieha (zm. 1707), podskarbi wielki litewski od $1676 \mathrm{r}$.

59 Aleksander Michał Wojna Jasieniecki (zm. 1698), kasztelan nowogródzki od 1684 r.

${ }^{60}$ Symeon Kurosz (Kuroż), skarbik smoleński w latach 1682-1696. 
zapiszę, każdemu w cale oddali. O czym JM ksiądz Adam Kmicic Societatis Jesu, synowiec mój wiedzieć ma. Na koniec oddając ducha mego Panu Bogu w ręce, żegnam świat, Ich MMściów panów synowców, bracią, siostry i wszystkich krewnych, tudzież wiernych sług moich, a w czymemkolwiek kogo kiedy uraził, przez miłość Zbawiciela mojego Jezusa Pana o wybaczenie każdego z osobna uniżenie upraszam i sam dla tejże miłości jego każdemu moję odpuszczam urazę. Do którego ostatniej woli mojej testamentu przy pieczęci mej, ręką własną podpisałem się. Tudzież Ich MMściów panów pieczętarzów ludzi godnych dla lepszej onegoż wiary o podpisanie rąk ustnie i oczewisto prosiłem, którzy Ich MM przy pieczęciami swych podpisali się. Pisan w Wilnie roku 1692, miesiąca stycznia dnia 20.

Do tego testamentu własną ręką moją podpisuję się Samuel Kmicic strażnik WKsL

Ustnie oczewisto proszony pieczętarz do tego testamentu od Wielmożnego JMści pana Samuela Kmicica strażnika WKsL podpisuję się Stanisław Popławski starosta kuniawski, pułkownik JKMści ${ }^{61}$.

Ustnie oczewisto do tego testamentu proszony pieczętarz od Wielmożnego JMści pana Samuela Kmicica strażnika WKsL podpisuję się Fortunat Zamoyski łowczy łomzieński ${ }^{62}$.

Ustnie i oczewisto do tego testamentu proszony pieczętarz od Wielmożnego JMści pana Samuela Kmicica strażnika WKsL podpisuję się Kazimierz Michał z Pusłowia Pusłowski podstoli rzeczycki ${ }^{63}$.

\section{Additament}

Co się kolwiek w samym testamencie opisało, to w tym additamencie do tegoż testamentu należącym ostatnią wolą moją wyrażam. Naprzód chcąc Ich MMściom panom krewnym moim i tu mój afekt pokazać, naznaczam JMści panu Kazimierzowi Kmicicowi staroście krasnosielskiemu złotych 1000 i 100 czerwonych złotych, JMści księdzu Adamowi Kmicicowi 1000 złotych i 100 czerwonych złotych,

${ }^{61}$ Stanisław Popławski (zm. 1703), chorąży rot husarskich hetmanów wielkich litewskich, najpierw M.K. Paca, a następnie K.J. Sapiehy, od ok. 1690 r. pułkownik armii litewskiej, dzierżawca starostwa koniawskiego i dubiskiego w woj. wileńskim po śmierci Jana Waleriana Kuncewicza $\mathrm{w} 1690 \mathrm{r}$.

62 Zamoyski był w 1692 r. jednym z najważniejszych urzędników Kazimierza Jana Sapiehy jako ekonom generalny jego dóbr.

${ }^{63}$ Kazimierz Michał Pusłowski (zm. 1696), podstoli rzeczycki od 1676 r., chorąży rot husarskich hetmanów polnych - M.K. Radziwiłła i K.J. Sapiehy, a następnie porucznik chorągwi husarskiej J.K. Dolskiego. 
JMści panu Onikiewiczowi złotych 1000, JMści panu Bakanowskiemu złotych 500, JMści panu Kuroszowi skarbnikowi smoleńskiemu złotych 500, JMści panu Adamowi Zakrzewskiemu złotych 500, JejMść paniej Tokarskiej złotych 500, JejMść paniej Paszkowskiej złotych 250, JMści panu Symonowi Zakrzewskiemu złotych 250, JMści panu Kazimierzowi Wodziewiczowi złotych 500, JMści panu Aleksandrowi Wodziewiczowi złotych 500, JMści panu Jerzemu Wodziewiczowi złotych 300, JMści panu Łyczkowskiemu złotych 500, JMści panu Romanowiczowi złotych 100, Ich MMściom Ojcom Dąbrowieckim złotych 100, Ich MMściom Pannom Bazyliankom orszańskim złotych 50. Na szpitale wileńskie złotych 100. Dworek za bramą wileńską na zborowej ulicy ${ }^{64}$ zapisuję JMści panu Kazimierzowi Kmicicowi, którego obowiązuję, aby połowę placu zajętego od Wielmożnego JMści pana Ciechanowieckiego oboźnego WKsL ${ }^{65}$ serio dochodził za prawami na to danemi, o com już processa pownosił. Przy tym niech się stara o restauracyją pomienionego dworku. Sumę, która zostaje, zostawuję do dalszej mojej dyspozycyjej. Jeśliby tak Ich MMściom panom krewnym, jako też Księży Ich MMściom w talarach płacono, tedy ma być przyjęty talar po złotych pół siódma. Com naznaczył sługom i czeladzi mojej, tego będzie osobliwy regestr z podpisem ręki mojej, według którego wszytkim zupełnie ma być oddano.

[podpis] Samuel Kmicic strażnik WKsL

Ustnie proszony pieczętarz od Wielmożnego JMści pana Samuela Kmicica strażnika WKsL do tej dyspozycyjej Krzysztoph Niemirowicz Szczyt starosta jaśwoński, stolnik połocki ${ }^{66}$ ręką swą.

Ustnie proszony pieczętarz od osoby wyż mianowanej do tej legacy rękę mą podpisuję Aleksander Woydziewicz.

Ustnie proszony pieczętarz od osoby wyż mianowanej do tej legacy podpisuję się Adam Zakrzewski lantwójt orszański

Ostatek additamentu: Na lampę przed ołtarz Najświętszej Panny w kościele wileńskim św. Ignacego, aby we dni święte i kiedy się msza święta będzie odprawowała (którom fundował) gorzała, naznaczam złotych 500. Kobierce, które są u JMści pana Karola Sokolińskiego ${ }^{67}$ w liczbie cztery, zapisuję do tegoż kościoła: dwa do ołtarza Świętego Krzyża, drugie dwa do ołtarza Panny Najświętszej, które ma odyskać ksiądz Adam Kmicic Societatis Jesu. JMści księdzu Adamowi

\footnotetext{
${ }^{64}$ Nieruchomość tę Kmicic miał zakupić niedługo przed sporządzeniem testamentu - 4 XII 1691 r.; T. Wasilewski, Kmicic Samuel..., s. 82.

${ }^{65}$ Albrycht Konstanty Ciechanowiecki (zm. 1675), oboźny litewski od 1663 r.

${ }^{66}$ Krzysztof Benedykt Niemirowicz Szczytt (zm. 1720), stolnik połocki w latach 1681-1697.

67 Zapewne Karol Michał Sokoliński (zm. ok. 1713).
} 
Kmicicowi Societatis Jesu, synowcowi memu zapisuję rydwan i cztery konie do niego co najlepsze, przy tym dwa kobierce nowe, którą w skarbcu moim wileńskim. Z sumy 2000 złotych będącej u Jaśnie Wielmożnego JMści pana wojewody połockiego ${ }^{68}$, na którą mam oblig przy sobie, zapisuję Ich MMściom Ojcom Dominikanom wileńskim u św. Ducha złotych 1000, Ich MMściom Ojcom Franciszkanom orszańskim z tejże sumy złotych 1000.

[podpis] Samuel Kmicic strażnik WKsL

\section{Aktykacja regestru przy testamencie w Bogu zeszłego Wielmożnego JMści pana Kmicica strażnika WKsL, Wilno, 4 IV 1692 r.}

Podstawa wydania: LVIA, f. SA, nr 35, k. 74-75v

Regestr, co ma być sługom i czeladzi dano, którzy mi w wojsku służyli i teraz służą, lubom onym zawsze jurgielta płacił i suchedni co czwierć, a barwę co rok dawałem i teraz, na urzędach niektórzy będąc, jurgielta biorą sobie należące. Jednak respektując na życzliwość onych, to naznaczam każdemu z osobna, Wilnie Anno 1692, Apryla dnia czwartego. Panu Sulewskiemu złotych 300, panu Jankowskiemu złotych 150, panu Morawińskiemu złotych 150, panu Borowskiemu złotych 120, panu Sulistrowskiemu złotych 60, panu Szabłowskiemu złotych 50, panu Pietraszce złotych 100, panu Rekuciowi starszemu 50, młodszemu na szkoły złotych 40. Czeladzi: Michałowi masztalerzowi złotych 60; temu jeżeliby osiad[ł] domem na Rusi, dać mu wolność, jako dają Kozakom i dać mu na zapomożenie jako na nowym gospodarstwie, temuż dać kontusz i żupan pakłakowy. Masztalerzowi Markowi Kozakowi złotych 40, Romanowskiemu masztalerzowi złotych 40 i barwę pakłakową, Polakowskiemu złotych 50 i kontusz tuzinkowy, a żupan pakłakowy. Siemionkowi woźnicy sukna pakłakowego łokci pięć i złotych 20, krawczykowi Hrehoremu sukna pakłakowego łokci pięć i złotych 20. Piekarczykowi także łokci pięć sukna pakłakowego i złotych 12. Pileckiemu i Janowi masztalerzowi po złotych 12, muzykantom kościelnym krasnosielskim po złotych 15, kucharzowi Janowi złotych 20, Janowi woźnicy barwę pakłakową i złotych 20, Marcinowi woźnicy przy stadzie będącemu pakłaku łokci pięć i złotych 20. Czeladzi drobniejszej folwarkowej, porachowawszy co komu będzie należało, w cale popłacić. Czego JM pan starosta ma pilnie dojrzeć, aby każdemu doszło co należy, żadnego jednak do służby nie przyniewalać okrom Polakowskiego.

[podpis] Samuel Kmicic strażnik WKsL

${ }^{68}$ Dominik Michał Słuszka (zm. 1713), wojewoda połocki od 1686 r. 


\section{Streszczenie}

Przedmiotem niniejszej edycji źródłowej jest testament strażnika litewskiego Samuela Kmicica jednego z najważniejszych dowódców średniego szczebla armii litewskiego drugiej połowy XVII w. Dokument ten został spisany w styczniu 1692 r., niespełna trzy miesiące przed śmiercią testatora, a na początku kwietnia dołączono do niego rejestr jego służby i czeladzi wojskowej.

Dotychczas zainteresowaniem polskich historyków cieszyły się tylko dwie sfery działalności Kmicica - wojskowa i polityczna. Testament pułkownika przede wszystkim znacznie poszerza stan wiedzy na temat jego statusu majątkowego, jak również powiązań finansowych z kolejnymi patronami - Jerzym Karolem Hlebowiczem, Michałem Kazimierzem Radziwiłłem czy też wreszcie Kazimierzem Janem i Benedyktem Pawłem Sapiehami. Źródło to ukazuje, że Samuel odgrywał bardzo ważną rolę w strukturach fakcji sapieżyńskiej i radziwiłłowskiej głównie dzięki znaczącemu kapitałowi, który udało mu się zgromadzić podczas trwającej kilka dekad służby wojskowej. Ponadto znajdujemy w nim ciekawe informacje na temat bardzo bliskich więzów łączących klientelę wojskową Sapiehów na przełomie lat 80. i 90. XVII w., a więc w czasie, gdy rodzina ta - głównie dzięki pełnej kontroli nad armią litewską - sprawowała niepodzielną hegemonię polityczną w Wielkim Księstwie Litewskim. Edycja ta zatem może stanowić cenny wkład do badań nad patronatem wojskowym w Rzeczypospolitej epoki nowożytnej.

Testament Samuela Kmicica zawiera również wiele szczegółów na temat jego stosunków rodzinnych, jak też działalności fundacyjnej, będących ważnymi uzupełnieniami do jego biografii.

\section{A Last Will of Lithuanian Grand Sergeant Samuel Kmicic Summary}

The subject of this source edition is a last will and testament of Great Lithuanian Sergeant Samuel Kmicic - one of the most important middle level commanders in the Lithuanian army in the second part of the seventeenth century. The document was written down in January 1692, less than three months prior to the testator's death; in the early April that year it was completed by a register of his household and military servants.

Thus far, historians' interest has been focused mainly on two spheres of Kmicic's activity - military and political ones. The colonel's last will broadens considerably our knowledge of his financial status as well as his ties to his successive patrons: Jerzy Karol Hlebowicz, Michał Kazimierz Radziwiłł, or finally Kazimierz Jan and Benedykt Paweł Sapiehas. The document demonstrates that Samuel played a very important part within the structures of the Sapiehas and Radziwiłłs party, mainly due to the significant capital he had been able to accumulate during his decades-long military service. It also contains interesting information about very close relations among the military clientage of the Sapiehas in the late 1680s and early 1690s, that is at the time when the family - mainly thanks to their full control over the Lithuanian army - extended their political economy over the Grand Duchy of Lithuania. The edition of this source is therefore a valuable contribution to the research into the military patronage in the early modern Polish-Lithuanian Commonwealth.

Samuel Kmicic's last will also contains a number of interesting details about his family relations as well as his foundation activities that are an important completion to his biography.

\section{Bibliografia}

\section{Źródła rękopiśmienne}

Archiwum Główne Akt Dawnych w Warszawie (AGAD)

Archiwum Warszawskie Radziwiłłów (AR), dz. V, nr 4488, 6873, 6874.

Archiwum Zamoyskich, sygn. 3112. 
Lietuvos valstybès istorijos archyvas (LVIA), f. SA, $\mathrm{nr} 11,14,15,23,27,28,31,35,3414,3418,4106$, $4111,4114$.

Нацыянальны гістарычны архіў Беларусі (NGAB), f. 1705, op. 1, nr 8, 24; f. 1875, op. 1, nr 1, 2, 4. Національна бібліотека України им. В.I. Вернадського, Kijów, f. 1, nr 5953.

Российский государственный архив древних актов (RGADA), f. 389, nr 137, 142.

\section{Źródła drukowane}

Boniecki A., Herbarz polski, t. 10, Warszawa 1907.

Chrapowicki J.A., Diariusz, cz. 3: Lata 1669-1673, oprac. L.A. Wierzbicki, Warszawa 2009.

Metryka Litewska. Ksiegga wpisów nr 131, oprac. A. Rachuba, Warszawa 2001.

Odlanicki-Poczobut J.W., Pamiętnik (1640-1684), oprac. A. Rachuba, Warszawa 1987.

Urzędnicy centralni i dostojnicy Wielkiego Księstwa Litewskiego XIV-XVIII wieku. Spisy, oprac.

H. Lulewicz, A. Rachuba, Kórnik 1994.

Volumina legum, t. 5, wyd. J. Ohryzko, Sankt Petersburg 1860.

\section{Opracowania}

Bobiatyński K., Kampania letnia 1664 roku na terytorium Wielkiego Księstwa Litewskiego - nieznany fragment wojny Rzeczypospolitej z Moskwa 1654-1667, w: Wojsko, wojskowość, miasta. Studia poświęcone prof. Stanisławowi Herbstowi w stulecie urodzin, red. K. Bobiatyński, P. Gawron, M. Nagielski, Zabrze 2009, s. 224-246.

Bobiatyński K., Michał Kazimierz Pac - wojewoda wileński, hetman wielki litewski. Działalność polityczno-wojskowa, Warszawa 2008.

Bobiatyński K., Militarne uwarunkowania negocjacji polsko-moskiewskich w Andruszowie w latach 1666-1667, w: Studia z dziejów stosunków Rzeczypospolitej z Państwem Moskiewskim w XVI-XVII wieku, red. M. Nagielski, K. Bobiatyński, P. Gawron, Zabrze-Tarnowskie Góry 2013, s. 385-403.

Bobiatyński K., Od Smoleńska do Wilna. Wojna Rzeczypospolitej z Moskwa 1654-1655, Zabrze 2004.

Bobiatyński K., Stosunki Jana III Sobieskiego z litewską elita władzy w pierwszym okresie rządów (1674-1676), w: Sobieski wokół spisków i konfederacji, red. M. Nagielski, Warszawa 2015 (Biblioteka Epoki Nowożytnej, t. 2), s. 129-143.

Bobiatyński K., W walce o hegemonię. Rywalizacja polityczna w Wielkim Księstwie Litewskim w latach 1667-1674, Warszawa 2016.

Bobiatyński K., Hundert Z., Skład armii Wielkiego Księstwa Litewskiego podczas wojny z Turcja (16751676) w świetle akt skarbowo-wojskowych, „Zapiski Historyczne” 83, 2018, nr 1, s. 155-173.

Czapliński W., Glosa do Trylogii, wyd. 2, Białystok 1999.

Dzieje rodziny Ciechanowieckich herbu Dąbrowa (XIV-XXI wiek), wyd. H. Lulewicz, A. Rachuba, J. Sikorska-Kulesza, S. Dumin, A. Haratym, A. Macuk, A. Pospiszil, red. A. Rachuba, Warszawa 2013.

Encyklopedia wiedzy o jezuitach na ziemiach Polski i Litwy 1564-1995, oprac. L. Grzebień, Kraków 1996.

Hundert Z., Husaria koronna w wojnie polsko-tureckiej 1672-1676, Oświęcim 2012.

Hundert Z., Projekty komputów wojska Wielkiego Księstwa Litewskiego z lat 1683-1684. Przyczynek do badań nad problemem rywalizacji Jana III $z$ Sapiehami o wplywy w wojsku litewskim w latach 1683-1696, „Rocznik Lituanistyczny” 3, 2017, s. 95-119.

Kersten A., Sienkiewicz - „Potop” - historia, Warszawa 1966.

Kołodziej R., „Ostatni wolności naszej klejnot”. Sejm Rzeczypospolitej za panowania Jana III Sobieskiego, Poznań 2014. 
Kosman M., Na tropach bohaterów „Trylogii”, wyd. 5, Warszawa 1996.

Kossarzecki K., Działalność wojskowa pułkownika Iwana Nieczaja na Białorusi w latach 1657-1659, „Україна в Центрально-Східній Европі” 2005, nr 5, s. 359-391.

Kossarzecki K., Forteca w Kopysi nad Dnieprem w latach wojny Rzeczypospolitej $z$ Moskwa 1654-1667, „Studia z Dziejów Wojskowości” 1, 2012, s. 129-175.

Kossarzecki K., Kampania roku 1660 na Litwie, Zabrze 2005.

Kossarzecki К., Кампанія 1660 году ў Літве, Менск 2011.

Kossarzecki K., Wojna z Państwem Moskiewskim na ziemiach Wielkiego Księstwa Litewskiego w latach 1658-1661, Warszawa 2007, mps pracy doktorskiej pod kier. prof. dr. hab. M. Nagielskiego, IH UW.

Majewski A.A., Aleksander Hilary Połubiński (1626-1679), marszałek wielki litewski. Działalność polityczno-wojskowa, Warszawa 2017.

Marcinkowski K., Stefan Czarniecki $w$ dobie potopu szwedzkiego (kampania nad Wisła i Sanem r. 1655/56), Kraków 1935.

Matwijów M., Ostatnie sejmy przed abdykacja Jana Kazimierza: 1667 i 1668, Wrocław 1992.

Paszenda J., Budowle jezuickie w Polsce: XVI-XVIII w., t. 4, Kraków 2010.

Płosiński J., Potop szwedzki na Podlasiu 1655-1657, Zabrze 2006.

Płosiński J., Wyprawa kniazia Semena Urusowa na Brześć (listopad - grudzień 1655 r.), „Mazowieckie Studia Humanistyczne" 2003, nr 1-2, s. 5-31.

Podhorodecki L., Kampania polsko-szwedzka 1659 r. w Prusach i Kurlandii, „Studia i Materiały do Historii Wojskowości" 4, 1958, s. 203-264.

Rachuba A., Konfederacje wojska litewskiego w latach 1655-1663, Zabrze 2010.

Rachuba A., Sokoliński (Drucki Sokoliński) Michał Leon, w: PSB, t. 40, Warszawa-Kraków 2000-2001, s. 46-49.

Rachuba A., Sprawa dóbr Radziwiłłów birżańskich w latach 1655-1662, „Miscellanea Historico-Archivistica" 7, 1997, s. 51-67.

Rachuba A., Wielkie Księstwo Litewskie wobec rokoszu Jerzego Lubomirskiego w latach 1664-1667, Warszawa 1979, mps pracy doktorskiej pod kier. dr. hab. T. Wasilewskiego, IH UW.

Sawicki M., Dom Sapieżyński 1666-1685. Droga do hegemonii w Wielkim Księstwie Litewskim, Opole 2016.

Wagner M., Wojna polsko-turecka w latach 1672-1676, t. 2, Zabrze 2009.

Wasilewski T., Kmicic Samuel, w: PSB, t. 13, Wrocław 1967-1968, s. 81-83.

Wasilewski T., Pierwowzór Sienkiewiczowskiego Kmicica, „Mówią Wieki” 2, 1959, nr 4, s. 12-15.

Wasilewski T., Przygody pana Samuela Kmicica, pułkownika wojsk JKM w latach potopu, „Mówią Wieki" 15, 1972, nr 2, s. 5-10.

Wasilewski T., Wyprawy wojenne pułkownika Samuela Kmicica, chorążego orszańskiego, w latach 1659-1665, „Mówią Wieki” 16, 1973, nr 10, s. 4-9.

Konrad Bobiatyński (ur. 1977) - dr hab., adiunkt w Zakładzie Historii Nowożytnej w Instytucie Historycznym Uniwersytetu Warszawskiego. Zainteresowania naukowe: historia Wielkiego Księstwa Litewskiego w drugiej połowie XVII w., staropolska sztuka wojenna XVI-XVII w. Autor książek: Od Smoleńska do Wilna. Wojna Rzeczypospolitej z Moskwa 1654-1655 (Zabrze 2004), Michat Kazimierz Pac - wojewoda wileński, hetman wielki litewski. Działalność polityczno-wojskowa (Warszawa 2008), Ад Смоленску да Вільні. Вайна Рэчы Паспалітай з Масковіяй (1654-1655 г2.) (wyd. 1: Mińsk 2008, wyd. 2: Wilno-Białystok 2011, wyd. 3: Smoleńsk 2014), W walce o hegemonię. Rywalizacja polityczna $w$ Wielkim Księstwie Litewskim w latach 1667-1674 (Warszawa 2016) oraz ponad 60 artykułów naukowych. E-mail: k_bob@wp.pl 